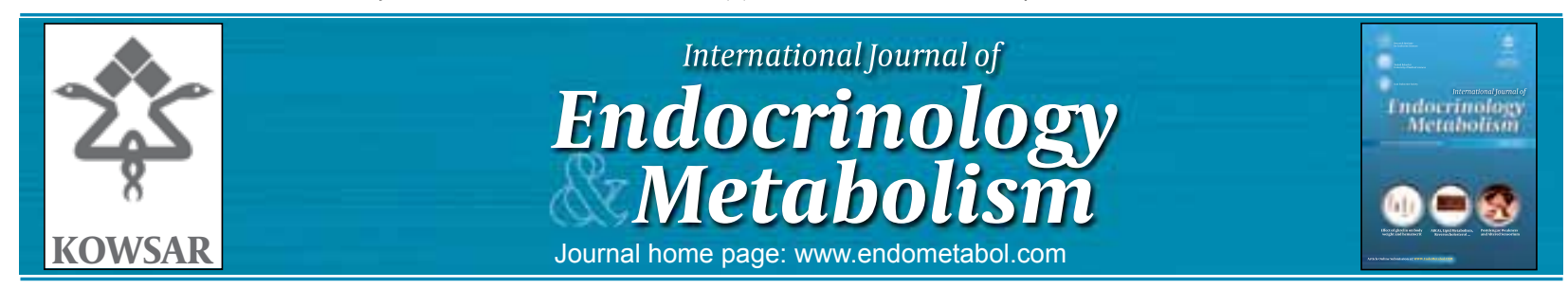

\title{
Prevention of Childhood Obesity
}

\section{Fereidoun Azizi $1^{1^{*}}$}

${ }^{1}$ Endocrine Research Center, Research Institute for Endocrine Sciences, Shahid Beheshti University of Medical Sciences, Tehran, IR Iran

\begin{tabular}{l}
\hline A R T I C L E I N F O \\
\hline Article Type: \\
Editorial \\
\hline Article history: \\
Received: 03 Dec 2010 \\
Revised: 22 Dec 2010 \\
Accepted: 24 Dec 2010 \\
\hline Keywords: \\
Obesity \\
Triglyceride \\
Choesterol \\
\hline
\end{tabular}

The World Health Organization has been working with its member states to reduce childhood obesity by implementing the "Global Strategy on Diet, Physical Activity, and Health" (1). The number of overweight and obese children worldwide has been estimated at over 155 and 45 million, respectively $(2,3)$. In other words, 1 out of every 8 children in the world has excess weight. The early consequences of obesity in children and adolescents are hyperlipidemia, insulin resistance, and hypertension in the pediatric age group (4). Furthermore, in recent years, an increasing number of complications, including type 2 diabetes, fatty liver, and orthopedic, respiratory, and sleep disorders have been reported $(5,6)$. This trend of increasing pediatric obesity is seen not only in developed countries, but also in developing countries (7). An alarming prevalence of childhood and adolescent obesity has been reported in Middle Eastern countries (8). For example, in Iran, the Tehran Lipid and Glucose Study (TLGS) and other investigations have reported a disturbing rise in the rate of excess weight in the pediatric age group $(9,10)$. In $9 \%$ of boys and $7 \%$ of girls, 2 or more non-communicable disease risk factors were seen, and the prevalence of hypertension, obesity, high cholesterol, elevated

\footnotetext{
* Corresponding author at: Fereidoun Azizi, Endocrine Research Center, Research Institute for Endocrine Sciences, Shahid Beheshti University of Medical Sciences, P.O. Box: 19395-4763, Tehran, IR Iran. Tel: +982122409309, Fax: +98-2122402463, E-mail: azizi@endocrine.ac.ir DOI: 10.5812/Kowsar.1726913X.1871

Copyright $\odot 2011$, Iran Endocrine Society, Published by Kowsar M.P.Co. All rights reserved.
}

- Implication for health policy/practice/research/medical education:

Emphasis on great complications of childhood obesity and global need for effective primary prevention.

- Please cite this paper as:

Azizi F. Prevention of Childhood Obesity. Int J Endocriol Metab. 2011;9(1): 246-7. DOI: 10.5812/Kowsar.1726913X.1871

๑ 2011 Kowsar M.P.Co. All rights reserved.

triglycerides, and low HDL was $12.7 \%, 5.2 \%, 5.1 \%, 5.0 \%$, and $10.2 \%$, respectively (11). The accumulation of risk factors is also rather prevalent, and $10 \%$ of adolescents fulfill the criteria for metabolic syndrome (12).

Overweight and obesity in childhood and adolescence increase the risk of coronary heart disease (CHD) in adulthood $(13,14)$, and the prevalence of CHD has been predicated to increase $5 \%-16 \%$ by 2035 . Therefore, according to Ludwig's hypothesis, we have passed phase 1 (increased prevalence of pediatric obesity) and phase 2 (increased complications such as type 2 diabetes, fatty liver, etc.) of the obesity epidemic, and we are entering phase 3 , which projects a rise in adult CHD in those suffering from excess weight and obesity during childhood (15). It has been predicted that this process may shorten life expectancy in the United States by $2-5$ years by midcentury; equal to all cancers combined (16). Are people waiting to see phase 4 of Ludwig's hypothesis, an acceleration of obesity through transgenerational mechanisms in the late 21st century, including irreversible biologic changes in hormonal pathways, fat cells, and the brain that increase hunger and adversely affect metabolism, and affection of offspring through prenatal programming? All these thoughts point to the urgent need of a global effort for effective intervention (17). There is broad consensus that pediatric obesity can be prevented by correction of dietary and lifestyle habits and increased physical activity, which should begin from pregnancy and infancy onward (18). However, no comprehensive strategy to en- 
courage family members, in particular children, exists. There is no simple solution, and we have proposed that a country's programs must focus on primary prevention with structured programs for lifestyle modifications. Parents must take responsibility for their children's health by modifying their own lifestyle and ensuring healthy lifestyles for their children, encouraging more physical activity and less television and computer viewing. These family efforts should be accompanied by governmental and private sector initiations to provide high quality food in the market and to curtail the ever-increasing manufacture of fast and junk foods. Without serious and adequate interventions, a catastrophe looms ahead (19).

\section{References}

1. Eastern Mediterranean Region Office. The Work of WHO in the Eastern Mediterranean Region. :Annual Report of the Regional Director 2003. [cited 2005; Jul: 20]; Available from: URL: http:/| www.emro.who.int/rd/AnnualReports/.

2. EU childhood obesity out of control. International Obesity Task Force. [cited 13.Jun.2005]; Available from: www.iotf.org.

3. World Health Organization. Obesity: an epidemic. World Health Organization. Geneva 2000. [cited 13.Jun.2005.]; Available from: http://www.emro.who.int/nutrition/PDF/Obestity_Epidemic.pdf. .

4. Freedman DS, Dietz WH, Srinivasan SR, Berenson GS. The relation of overweight to cardiovascular risk factors among children and adolescents: the Bogalusa Heart Study. Pediatrics. 1999;103(6 Pt 1):1175-82.

5. Dietz WH. Health consequences of obesity in youth: childhood predictors of adult disease. Pediatrics. 1998;101(3 Pt 2):518-25.

6. Must A. Morbidity and mortality associated with elevated body weight in children and adolescents. Am J Clin Nutr. 1996;63(3 Suppl):445S-7S.

7. De Onis M, Blössner M. Prevalence and trends of overweight among preschool children in developing countries. The Amer $j$ clin nutr. 2000;72(4):1032.

8. Mirmiran P, Sherafat-Kazemzadeh R, Azizi F. Prevalence of childhood overweight and obesity in the Middle East: a review on current literature. East Medit Health J. 2008.

9. Azizi F, Allahverdian S, Mirmiran P, Rahmani M, Mohammadi F. Dietary factors and body mass index in a group of Iranian adolescents: Tehran lipid and glucose study-2. Int J Vitam Nutr Res. 2001;71(2):123-7.

10. Kelishadi R, Pour MH, Sarraf-Zadegan N, Sadry GH, Ansari R, Alikhassy $\mathrm{H}$, et al. Obesity and associated modifiable environmental factors in Iranian adolescents: Isfahan Healthy Heart Program - Heart Health Promotion from Childhood. Pediatr Int. 2003;45(4):435-42.

11. Mohammadpour-Ahranjani B, Rashidi A, Karandish M, Eshraghian MR, Kalantari N. Prevalence of overweight and obesity in adolescent Tehrani students, 2000-2001: an epidemic health problem. Public Health Nutr. 2004;7(5):645-8.

12. Azizi F, Salehi P, Etemadi A, Zahedi-Asl S. Prevalence of metabolic syndrome in an urban population: Tehran Lipid and Glucose Study. Diabetes Res Clin Pract. 2003;61(1):29-37.

13. Baker JL, Olsen LW, Sorensen TI. Childhood body-mass index and the risk of coronary heart disease in adulthood. $N$ Engl J Med. 2007;357(23):2329-37.

14. Bibbins-Domingo K, Coxson P, Pletcher MJ, Lightwood J, Goldman L. Adolescent overweight and future adult coronary heart disease. N Engl J Med. 2007;357(23):2371-9.

15. Ludwig DS. Childhood obesity--the shape of things to come. $N$ Engl J Med. 2007;357(23):2325-7.

16. Olshansky SJ, Passaro DJ, Hershow RC, Layden J, Carnes BA, Brody $\mathrm{J}$, et al. A potential decline in life expectancy in the United States in the 21st century. N Engl J Med. 2005;352(11):1138-45.

17. Pradinuk M, Chanoine JP, Goldman RD. Obesity and physical activity in children. Can Fam Physician. 2011;57(7):779-82.

18. Wojcicki JM, Heyman MB. Let's move-childhood obesity prevention from pregnancy and infancy onward. $N$ Engl J Med. 2010;362(16):1457-9.

19. Azizi F, Mirmiran P, Sherafat-Kazemzadeh R. Pediatric obesity: an impending catastrophe. Arch Iran Med. 2008;11(2):242-5. 